\title{
In vitro Synergistic Antimicrobial Activity of Romanian Propolis and Antibiotics against Escherichia coli Isolated from Bovine Mastitis
}

\author{
Mihaela NICULAE ${ }^{1}$, Laura STAN²* Emőke PALL ${ }^{1}$, Anamaria Ioana PAȘTIU ${ }^{1}$, \\ Iulia Maria BALACI ${ }^{1}$, Sevastiţa MUSTE ${ }^{2}$, Marina SPÎNU ${ }^{1}$ \\ ${ }^{1}$ University of Agricultural Sciences and Veterinary Medicine, Faculty of Veterinary Medicine, 3-5 Manastur Street, 400372, Cluj-Napoca, \\ Romania;mihaela.niculae@usamvcluj.ro \\ ${ }^{2}$ University of Agricultural Sciences and Veterinary Medicine, Faculty of Food Science and Technology, 3-5 Manastur Street, 400372, Cluj-Napoca, \\ Romania;laurastan@usamvcluj.ro('correspondingauthor)
}

\begin{abstract}
The study was aimed to characterize the chemical composition and the antimicrobial activity of Romanian propolis ethanolic extracts (EEP) against antibiotic-sensitive and antibiotic-resistant $E$. coli strains isolated from bovine mastitis. The preliminary antimicrobial screening was performed by a disk diffusion method, followed by determination of minimum inhibitory concentrations (MIC) and minimum bactericidal concentrations (MBC) based on broth microdilution assay; further, the synergistic action of propolis with antimicrobial drugs was assessed by a disk diffusion method on agar containing subinhibitory concentrations of propolis. For the chemical characterisation of EEP, the flavonoids (flavones/flavonols, flavanones/dihydroflavonols) and total phenolics were evaluated by spectrophotometric methods. The phenolic compounds of these extracts were also determined using HPLC. The results indicated for Romanian propolis ethanolic extracts the typical poplar composition profile with flavonoids and phenolic acids as main biological active compounds, with chromatographic analysis data confirmed also spectrophotometrically. In addition, positively correlated with the chemical composition, a strong antimicrobial efficacy was exhibited towards $E$. coli strains, along with interesting synergistic interaction with antibiotics that can be further investigated to obtain propolis-based formulation with antibacterial properties. Subsequent in vitro and in vivo studies evaluating the safety and efficacy are intended to consider propolis in veterinary therapeutic protocols.
\end{abstract}

Keywords: antibacterial, antimicrobial resistance, ethanolic extracts, flavonoids, phenolics

\section{Introduction}

Bovine mastitis is described as one of the most significant diseases affecting dairy herds, a pathology leading to considerable financial losses to the bovine industry due to the costs associated with diagnostics, treatment, redundancy (milk production losses, discarded milk) and animal culling (Halasa et al., 2007; Viguier $e t$ al., 2009; Down et al., 2013; Hegazi et al., 2014). Since the etiology of bovine mastitis involves bacterial pathogens, such as Escherichia coli, Staphylococcus aureus and Streptococcus uberis(Bradley, 2002; Hegazi et al., 2014), the use of antimicrobials (intramammary infusion and systemic administration) represents a fundamental part of the therapeutic protocols. Unfortunately, as one of the most important consequences of the intensive and/or inappropriate use of antimicrobials, elevated levels of antimicrobial resistance are currently reported in cases of mastitis etiological agents, with particular reference to E. coli (Bradley, 2002; Viguier et al., 2009; Hegazi et al., 2014).
Worldwide, the emergence of antibiotic-resistant microorganisms triggered the search for alternatives such as natural products with antimicrobial activity (Nweze and Eze, 2009; Hegazi et al., 2014). The stringent need of research into natural alternatives to antimicrobials is emphasized also by the current farm animal health and welfare policies (Ruegg, 2009).

Propolis may represent a valid choice, in the view of bioavailability and complex therapeutic potential conferred by its rich content in biologically active compounds. Defined as a natural product derived from plant resins collected by honeybees (Apis mellifica L.) (Khalil, 2006), propolis is well-known as a highly valuable natural remedy with a multitude of biological and pharmacological properties, namely antibacterial (Dobrowolski et al., 1991; Marcucci et al., 2001; Kosalec et al., 2005; Seidel et al., 2008; Silva et al., 2012; Stan et al., 2012), antiviral (Gekker et al., 2005; Schnitzler et al., 2010), antifungal (Dobrowolski et al., 1991; Quiroga et al., 2006), antioxidant (De Castro, 2001; Kalogeropoulos et al., 2009), anti-inflammatory (Dobrowolski et al., 1991; Banskota et al., 2001; Lotfy, 2006; Silva et al., 2012), 
328

immunomodulatory (Kosalec et al., 2005; Lotfy, 2006; Rindt et al., 2009b), wound healing (Pascoal et al., 2014), hepatoprotective (Banskota et al., 2001), anti-ulcer (Lotfy, 2006) and anti-tumor activities (Banskota et al., 2001; Oršolić, 2010).

Not only the biological properties are complex, but also the chemical composition features, with more than 300 identified compounds such as polyphenols, phenolic aldehydes, sequiterpene quinines, coumarins, amino acids, steroids and inorganic compounds (Kosalec et al., 2005; Khalil, 2006) and content variations depending on the collecting location, time and plant source (Bankova et al., 2002; Melliou and Chinou, 2004; Salomão et al., 2004; Bankova, 2005; Popova et al., 2005; Sahinler and Kaftanoglu, 2005; Uzel et al., 2005; Gonsales et al., 2006; Khalil, 2006; Popova et al., 2007; Barbarić et al., 2011; Mărghitaş et al., 2013; Huang et al., 2014).

Scientific data regarding Romanian propolis are documented in the literature, mostly about the chemical composition, quality criteria for standardization and certain biological properties (Laslo, 2007; Rindt et al., 2009a, 2009b; Stan et al., 2011; Stan et al., 2012; Mărghitaş et al., 2013). Still, the growing interest in the veterinary apitherapy requires more research studies to substantiate the therapeutic use of propolis. Few studies investigated the synergistic effects between propolis and antibiotics (Stepanovic et al., 2003, Orsi et al., 2006) and no studies regarding the synergistic effect of Romanian propolis with other drugs have been done.

Therefore, taking into consideration the importance of new scientific research relating Romanian propolis, this study was aimed to investigate in vitro antibacterial activity of propolis ethanolic extracts tested alone and in combination with five antibiotics against $E$. coli strains isolated from bovine presenting clinical mastitis.

\section{Materials and Methods}

Propolissamples

Five propolis samples were collected from the following Romanian counties: Satu Mare (sample 1), Maramures (sample 2), Salaj (sample 3), Cluj (sample 4) and Bihor (sample 5) and stored in the freezer $\left(-20^{\circ} \mathrm{C}\right)$ until analysis.

\section{Extraction of active principles from propolis}

Extraction of active principles from propolis (finely grounded) was performed by maceration with $70 \%$ ethanol (final concentration $1: 100, \mathrm{w} / \mathrm{v}$ ) with continuous stirring at 400 rpm for $24 \mathrm{~h}$. The ethanolic extract was further diluted in optimal concentrations needed for quantitative analysis according to methods described by Popova et al. (2004). Extraction was realized in triplicate for all samples. All ethanolic extracts of propolis (EEP 1-5) were kept in the dark until anti $E$. coli activity analysis was performed.

Quantitative determination offlavonoids and total phenolics

Spectrophotometric methods were carried out for quantitative determination of flavonoids (flavones/flavonols, flavanones/dihydroflavonols) and total phenolics (Folin Ciocalteu method) from all EEP (Popova et al., 2004).

Spectrophotometric method from Popova et al. (2004) was adapted to determine the flavones/flavonols: $1 \mathrm{ml}$ of EEP was added to $0.5 \mathrm{ml}$ of $5 \%$ aluminium chloride and adjusted to $25 \mathrm{ml}$ with methanol. The solution was left to stand in the dark for $30 \mathrm{~min}$ and the absorbance was measured at $425 \mathrm{~nm}$ against blank. Standard solution of galangin $(0.5 \mathrm{mg} / \mathrm{ml})$ was prepared for calibration curve. For each calibration curve five concentration levels were prepared and three independent determinations were performed for each concentration $(n=3)$. The equation obtained for flavones/flavonols was $\mathrm{Y}=2.04832^{*}$ $\mathrm{X}-0.00233 ; \mathrm{r}^{2}=0.99935$.

The protocol for flavanones/dihydroflavonols evaluation was adapted after Popova et al. (2004): $1 \mathrm{ml}$ of propolis ethanolic extract was added to $2 \mathrm{ml}$ dinitrophenilhydrazine $(1 \mathrm{~g}$ dinitrophenilhydrazine was mixed with $2 \mathrm{ml} \mathrm{H}_{2} \mathrm{SO}_{4} 96 \%$ and diluted to $100 \mathrm{ml}$ with methanol). The obtained solution was heated at $50{ }^{\circ} \mathrm{C}$ for $50 \mathrm{~min}$. After cooling at room temperature, the solution was diluted to $10 \mathrm{ml}$ with $10 \% \mathrm{KOH}$ in methanol. An aliquot of $0.5 \mathrm{ml}$ was transferred into a volumetric flask and the volume was adjusted to $25 \mathrm{ml}$ methanol. Blank solution was prepared by replacing the amount of sample with methanol and carried out through all steps of the procedure. Standard solution of pinocembrin $(1 \mathrm{mg} / \mathrm{ml})$ was prepared for calibration curve (equation $\mathrm{Y}=0.11034^{*} \mathrm{X}-0.00416 ; \mathrm{r}^{2}=0.99910$ ). The absorbance was measured at $486 \mathrm{~nm}$ against blank.

Total phenolics were determined by Folin Ciocalteu method (Popova et al., 2004; Laslo, 2007). Briefly, $1 \mathrm{ml}$ of EEP was added to $4 \mathrm{ml}$ Folin-Ciocalteu reagent and $6 \mathrm{ml} 20 \%$ sodium carbonate and the volume was adjusted to $50 \mathrm{ml}$ with distilled water. The test solutions were kept in the dark for $2 \mathrm{~h}$ and then the absorbance was measured at $760 \mathrm{~nm}$ against blank. Standard mixture of pinocembrin:galangin $(2: 1, \mathrm{w} / \mathrm{w})$ was used for calibration curve (equation $\mathrm{Y}=0.00709^{*} \mathrm{X}-0.00109 ; \mathrm{r}^{2}=$ 0.99932).

\section{Phenolic compound identification (HPLC)}

Chromatographic separations of phonolic compounds from EEP were performed after adapted method previously published by Laslo (2007). Separation of phenolic compounds was carried out on HPLC - PDA Schimadzu, using a Supelcosil LC-18 column $(250 \mathrm{~mm} \times 4.6 \mathrm{~mm}$, particle size $5 \mu \mathrm{m})$ with Supelguard LC-18 guard- column (20 mm x $2.1 \mathrm{~mm}$, particle size $5 \mu \mathrm{m})$, using methanol/acetic acid/water as mobile system in the following ratio $10 / 2 / 88$ for phase $A$ and $90 / 3 / 7$ for phase $B$. Elution was performed at $1 \mathrm{ml} / \mathrm{min}$ flow rate and injection volume of $20 \mu \mathrm{l}$ using gradient method with the following timetable $(\mathrm{t} / \mathrm{min}, \% \mathrm{~B}):(0,0),(10,15),(30,50),(45,85),(55$, 100). Chromatograms were recorded at 280 and $340 \mathrm{~nm} .1 \%$ EEP prepared in ethanol HPLC were filtered through $0.45 \mu \mathrm{m}$ filters prior injection. The components of propolis extracts were identified by comparison with retention times of known chemical standards commonly found in propolis. Stock solutions of chemical standards of siringic acid, caffeic acid, vanillin, pcoumaric acid, sinapic acid, ferrulic acid, pinocembrin, chrysin, galangin, pinostrobin were prepared in ethanol HPLC (1 $\mathrm{mg} / \mathrm{ml}, \mathrm{w} / \mathrm{v})$. Concentration of separated compounds from EEP was determined using calibration curves expressed in $\mathrm{mg} / \mathrm{g}$ propolis.

\section{Escherichia colistrains}

The EEP were evaluated towards Escherichia coli strains ( $\mathrm{n}=$ 10) isolated from clinical cases of bovine mastitis. Both antibiotic-susceptible strains $(\mathrm{n}=5)$ and strains resistant $(\mathrm{n}=5)$ to amoxicillin/clavulanic acid, tetracycline, gentamycin, 
Table 1. Spectrophotometric quantitative determination of specific flavonoid groups and total phenolics in analyzed EEP

\begin{tabular}{cccc}
\hline \multirow{2}{*}{ Sample } & \multicolumn{3}{c}{ Average \pm Standard deviation } \\
\cline { 2 - 4 } & $\begin{array}{c}\text { Flavones/Flavonols } \\
\text { (mg/gpropolis) }\end{array}$ & $\begin{array}{c}\text { Flavanones/ } \\
\text { Dihydroflavonols } \\
\text { (mg/gpropolis) }\end{array}$ & $\begin{array}{c}\text { Total phenolics } \\
\text { (mg/gpropolis) }\end{array}$ \\
\hline 1 & $3.81 \pm 0.23$ & $2.75 \pm 0.04$ & $30.61 \pm 1.16$ \\
2 & $6.05 \pm 0.35$ & $1.96 \pm 0.26$ & $30.81 \pm 1.16$ \\
3 & $1.74 \pm 0.12$ & $3.32 \pm 0.18$ & $34.96 \pm 9.36$ \\
4 & $9.22 \pm 0.35$ & $3.92 \pm 0.12$ & $45.60 \pm 3.27$ \\
5 & $8.20 \pm 0.35$ & $4.01 \pm 0.13$ & $48.11 \pm 2.76$ \\
Mean & $5.80 \pm 3.08$ & $3.19 \pm 0.86$ & $38.02 \pm 8.30$ \\
\hline
\end{tabular}

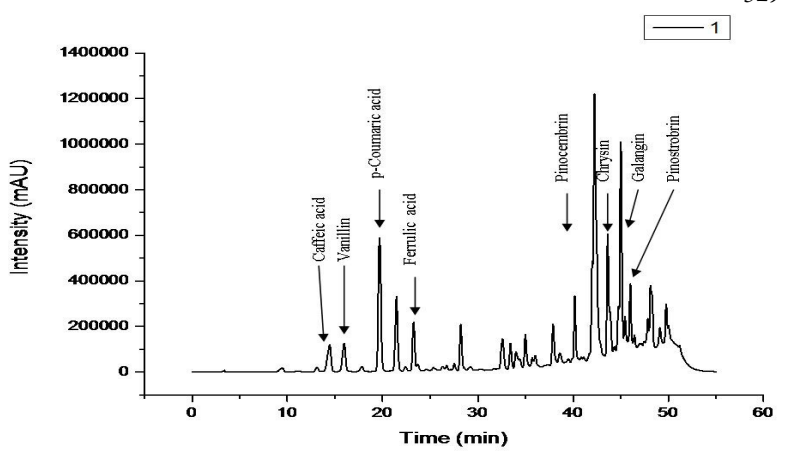

Table 2. Phenolics identified by HPLC in analyzed EEP

Fig. 1. HPLC Chromatogram of Sample 1

\begin{tabular}{|c|c|c|c|c|c|c|}
\hline \multirow{3}{*}{ Compound } & \multirow{3}{*}{$\begin{array}{c}\mathrm{RT} \\
(\mathrm{min})\end{array}$} & \multicolumn{5}{|c|}{ Content (mg/g propolis) } \\
\hline & & \multicolumn{5}{|c|}{ Sample } \\
\hline & & 1 & 2 & 3 & 4 & 5 \\
\hline Siringic acid & 12.85 & 0.00 & 0.00 & 0.22 & 0.00 & 0.00 \\
\hline Caffeic acid & 14.44 & 0.52 & 0.52 & 0.00 & 1.16 & 1.41 \\
\hline Vanillin & 15.86 & 0.24 & 0.04 & 0.49 & 0.13 & 0.28 \\
\hline p-Coumaric acid & 19.68 & 1.26 & 0.46 & 2.45 & 0.81 & 1.55 \\
\hline Sinapic acid & 21.02 & 0.00 & 0.00 & 0.03 & 0.00 & 0.00 \\
\hline Ferrulic acid & 24.90 & 1.02 & 0.39 & 2.39 & 0.13 & 0.70 \\
\hline Pinocembrin & 42.44 & 0.15 & 0.00 & 0.55 & 0.75 & 0.00 \\
\hline Chrysin & 43.70 & 1.22 & 2.37 & 0.59 & 2.75 & 2.27 \\
\hline Galangin & 44.59 & 0.02 & 0.58 & 0.00 & 0.00 & 0.00 \\
\hline Pinostrobin & 46.98 & 0.25 & 0.13 & 0.00 & 0.09 & 0.20 \\
\hline Total & & 4.68 & 4.49 & 6.72 & 5.82 & 6.41 \\
\hline Average & & 0.47 & 0.45 & 0.67 & 0.58 & 0.64 \\
\hline
\end{tabular}

enrofloxacin and florfenicol were selected for this assay and Escherichia coli ATCC ${ }^{\circledR} 25922$ was also tested as a quality control organism. These microorganisms were cultivated on Mueller Hinton agar and $24 \mathrm{~h}$ pure colonies were used to prepare $1.5 \mathrm{x}$ $10^{8} \mathrm{cfu} / \mathrm{ml}$ inoculum.

The evaluation of the propolis ethanolic extracts antimicrobial potential

The antimicrobial potential of each propolis ethanolic extract was evaluated using an agar diffusion protocol similar to the standard Kirby-Bauer method according to the Clinical and Laboratory Standards Institute (CLSI, 2013) guidelines. The bacterial strains prepared as inoculum were inoculated on Mueller Hinton agar plates; sterile filter paper discs impregnated with $20 \mu \mathrm{l}$ EEP were applied and the inhibition zone diameters (IZD, mm) were recorded after $24 \mathrm{~h}$ incubation at $37^{\circ} \mathrm{C}$. The testing was performed in duplicate. Positive controls (antibiotics) and 70\% ethanol (EEP solvent) were included for each determination.

\section{Minimum inbibitory and minimum bactericidal} concentrations determination

The minimum inhibitory (MIC) and minimum bactericidal (MBC) concentrations were established using a broth microdilution method, with twofold serial dilutions of each EEP, ranging from $4 \%$ to $0.125 \%(\mathrm{v} / \mathrm{v})$, mixed with an equal volume of bacterial inoculum and incubated for $24 \mathrm{~h}$ at $37^{\circ} \mathrm{C}$, when the MICs values were determined considering the lowest concentrations of EEP able to inhibit the visible growth of bacteria (no turbidity), when compared to the control. Afterwards, $10 \mu \mathrm{l}$ of each EEP dilution were cultured on
Mueller agar plates for $24 \mathrm{~h}$ at $37{ }^{\circ} \mathrm{C}$ and the lowest concentrations associated with no visible bacterial growth on the agar plates (no colonies) were recorded as the MBCs. The effect type on the $E$. coli strains was also investigated based on the value of MBC/MIC (bactericidal if MBC/MIC $<4$ or bacteriostatic for $\mathrm{MBC} / \mathrm{MIC} \geq 4$ ) according to method previously described (Pavithra et al., 2010).

\section{Evaluation of the interaction between the EEP and antibiotics}

In order to evaluate the anti $E$. coli efficacy of EEP and antibiotic combinations, the agar diffusion method was carried out as previously described by Nweze and Eze (2009). Briefly, the bacterial strains prepared as inoculum were cultured on Mueller Hinton agar mixed with sub-inhibitory concentration of EEP and tested against five antimicrobials: amoxicillin/clavulanic acid (AMC, 20/10 $\mu \mathrm{g}$ ), tetracycline (TE, $30 \mu \mathrm{g}$ ), gentamycin (CN, $10 \mu \mathrm{g}$ ), enrofloxacin (ENR, 5 $\mu \mathrm{g})$ and florfenicol (FFC, $30 \mu \mathrm{g})$. After $24 \mathrm{~h}$ of incubation at 37 ${ }^{\circ} \mathrm{C}$, the inhibition zone diameters (IZD) were measured. The results of the assay were expressed as percentage change in IZD compared to controls (IZD for antibiotics) and recorded as synergistic effect for IZD $\geq 19 \%$, additivity for IZD between 0$19 \%$ and antagonism for IZD < 0 (Nweze and Eze, 2009).

\section{Statistical analysis of results}

Statistical analysis of data was performed using the Microsoft Office Excel 2010 program. The results were expressed as average \pm standard deviation. Comparisons between antibiotics and EEP combinations were assessed by analysis of variance (ANOVA). In addition, Pearson's 
330

Table 3. In vitro antibacterial efficacy of tested propolis samples against

E. coli strains

\begin{tabular}{|c|c|c|c|c|c|}
\hline \multirow{2}{*}{ EEP } & \multirow{2}{*}{$\begin{array}{c}\text { IZD } \\
(\mathrm{mm})\end{array}$} & \multirow{2}{*}{$\begin{array}{c}\text { MIC } \\
\%(\mathrm{v} / \mathrm{v})\end{array}$} & \multirow{2}{*}{$\begin{array}{c}\text { MBC } \\
\%(\mathrm{v} / \mathrm{v})\end{array}$} & \multicolumn{2}{|r|}{$\mathrm{MBC} / \mathrm{MIC}$} \\
\hline & & & & Value & Interpretation \\
\hline \multicolumn{6}{|c|}{ E. coli antibiotic-susceptible strains $(\mathrm{n}=5)$} \\
\hline 1 & $21.5 \pm 0.7$ & 1 & 2 & 2 & bactericidal activity \\
\hline 2 & $20.5 \pm 0.7$ & 1 & 1 & 1 & bactericidal activity \\
\hline 3 & $21.0 \pm 1.4$ & 0.25 & 0.5 & 2 & bactericidal activity \\
\hline 4 & $24.5 \pm 2.1$ & 0.125 & 0.25 & 2 & bactericidal activity \\
\hline 5 & $25.0 \pm 1.4$ & 0.125 & 0.125 & 1 & bactericidal activity \\
\hline \multicolumn{6}{|c|}{ E. coli antibiotic-resistant strains $(\mathrm{n}=5)$} \\
\hline 1 & $17.5 \pm 0.7$ & 4 & 4 & 1 & bactericidal activity \\
\hline 2 & $16.5 \pm 0.7$ & 4 & 4 & 1 & bactericidal activity \\
\hline 3 & $19.0 \pm 0.0$ & 2 & 4 & 2 & bactericidal activity \\
\hline 4 & $19.5 \pm 0.7$ & 1 & 2 & 2 & bactericidal activity \\
\hline 5 & $17.0 \pm 0.0$ & 2 & 4 & 2 & bactericidal activity \\
\hline
\end{tabular}

arexpressed as average \pm standard deviation.

correlation coefficients were calculated between flavonoid groups, total phenolics and the values of MICs using CORREL function from Microsoft Office Excel 2010. Data were interpreted for significance level of $\mathrm{P} \leq 0.05$.

\section{Results and Discussion}

Chemical characterization of ethanolic extracts of propolis

The analysed propolis ethanolic extracts had a dark reddishbrown color, with a specific taste and smell of aromatic resins from Populus sp. To evaluate both total phenolics and flavonoids (flavones/llavonols and flavanones/dihydroflavonols), spectrophotometric methods were applied according to Popova et al. (2004), Bankova (2005) and Laslo (2007); spectrophotometric methods are fast and reliable methods compared to chromatographic which have the disadvantage to be more expensive. Total phenolics (Table 1) in the studied EEP ranged from 30.61 $\mathrm{mg} / \mathrm{g}$ propolis to $48.11 \mathrm{mg} / \mathrm{g}$ propolis. The lowest amount of phenolics was recorded for EEP 1 and 2, which were collected from mountain area, where fir is the main vegetal source of resins for propolis. EEP 4 and 5 presented the highest amount of total phenolics (over $45 \mathrm{mg} / \mathrm{g}$ propolis) and this is due to abundance of other vegetal sources of resins like pine, poplar and chestnut. These results are in agreement with previous reports on Romanian propolis composition (Laslo, 2007; Stan et al., 2011).

In general, EEP presented high amounts of total flavonoids $(9.00$ $\pm 3.94 \mathrm{mg} / \mathrm{g}$ propolis), where $1.74-9.22 \mathrm{mg} / \mathrm{g}$ belonged to the group of flavones/flavonols and $1.96-4.01 \mathrm{mg} / \mathrm{g}$ were flavanones/dihydroflavonols(Table 1).

The smallest amount of flavonoids was recorded for EEP 3 (about $5 \mathrm{mg} / \mathrm{g}$ propolis), although total phenolics were in average range (34.96 $\pm 9.36 \mathrm{mg} / \mathrm{g}$ propolis) compared to the other EEP $(38.02 \pm 8.30 \mathrm{mg} / \mathrm{g}$ propolis). This lead to assumption that EEP 3 had a higher concentration of phenolic acids, hypothesis that was further confirmed by HPLC results (Table 2), where data clearly showed that the highest concentration of p-coumaric acid and ferrulic acid was found in this case.

By HPLC analysis some specific compounds (Table 2) like siringic acid, caffeic acid, vanillin, p-coumaric acid, sinapic acid, ferrulic acid, pinocembrin, chrysin, galangin, pinostrobin were identified and quantified.

These compounds are considered typical for poplar type of propolis, which is mainly found in European temperate zone (Bankova, 2005; Laslo, 2007). All EEP presented most of aforementioned compounds. At the same time, specific phenolics like caffeic acid, galangin and pinostrobin were missing from sample 3 .

The most common compounds were represented by $\mathrm{p}$ coumaric acid, ferrulic acid and chrysin. P-coumaric acid was found in all EEP in concentration ranging from 0.46 (sample 2) to $2.45 \mathrm{mg} / \mathrm{g}$ propolis (sample 3), while siringic acid and sinapic acid were least present and found only in EEP 3 with concentration of $0.22 \mathrm{mg} / \mathrm{g}$ propolis and 0.03 $\mathrm{mg} / \mathrm{g}$ propolis, respectively.

Flavonoid chrysin was the main compound in propolis EEP in concentration ranging from $0.59 \mathrm{mg} / \mathrm{g}$ propolis (sample 3) to $2.75 \mathrm{mg} / \mathrm{g}$ propolis (sample 4), while galangin was completely absent in EEP 3, 4 and 5 and in very low amount in EEP 1 and 2 (0.02-0.58 $\mathrm{mg} / \mathrm{g}$ propolis).

Compared to Croatian propolis analysed by Barbarić et al. (2011) that had the ferrulic acid as the most commonly found phenolic acid (0.03-0.9 mg/g propolis), the EEP in our experiment identified the same compound, but in higher concentration $(0.13-2.39 \mathrm{mg} / \mathrm{g}$ propolis). Other components identified in Croatian propolis were: $\mathrm{p}$ coumaric acid in 16 samples out of 20 , with concentration ranging from $0.0023 \mathrm{mg} / \mathrm{g}$ to $0,156 \mathrm{mg} / \mathrm{g}$ propolis, chrysin in only 8 samples and in the range between $0.7-4.1 \mathrm{mg} / \mathrm{g}$ propolis and galangin in 17 samples and with higher concentration (0.37-47.48 mg/g propolis) (Barbarić et al., 2011).

Previous chemical studies proved the complexity of propolis composition that varies with botanical and geographical origin (Bankova et al., 2002; Melliou and Chinou, 2004; Salomão et al., 2004; Bankova, 2005; Popova et al., 2005; Sahinler and Kaftanoglu, 2005; Uzel et al., 2005; Gonsales et al., 2006; Khalil, 2006; Popova et al., 2007; Barbarić et al., 2011; Huang et al., 2014). The main propolis types are represented by: poplar type (Europe temperate areal), birch propolis (Russia), green propolis (Brazil), red propolis (Cuba) (Bankova, 2005). Romanian propolis belongs to poplar type, since pine, poplar, chestnut and fir are the main vegetal sources of resins for honey bees to prepare the propolis (Laslo, 2007). According to Bankova (2005) typical poplar type propolis has the following compositional characteristics: $8 \pm 4 \%$ flavones/flavonols, $6 \pm 2 \%$ flavanones/dihydroflavonols and $28 \pm 9 \%$ total phenolics. However, scholars recorded high variation of phenolics content mainly due to various factors such as flora available to bees at collection site, climate and competition of bees over the same areal (Laslo, 2007; Mărghitaş et al., 2013).

\section{Antimicrobial activity of ethanolic extracts of propolis}

The antimicrobial potential of EEP was expressed in vitro against all tested $E$. coli strains, but with lower inhibition zone diameters in case of the antibiotic-resistant ones. The obtained diameters varied from $20.5 \pm 0.7 \mathrm{~mm}$ (EEP 2) to $25.0 \pm 1.4 \mathrm{~mm}$ (EEP 5) in case of antibioticsusceptible strains and $16.5 \pm 0.7 \mathrm{~mm}$ (EEP 2) to $19.5 \pm 0.7$ $\mathrm{mm}$ (EEP 4) for the antibiotic-resistant strains, respectively. All five EEP inhibited the growth of E. coli; the most intense inhibitory effect was recorded for EEP 4 and 5 (Table 3). 


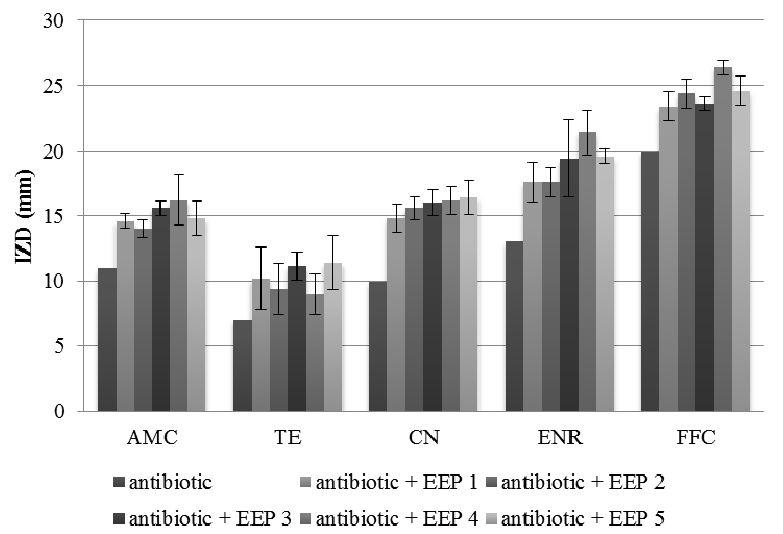

Fig. 2. Inhibition zone diameter (IZD) ( $\mathrm{mm}$ ) determined for EEP and antibiotics combination against $E$. coli antibiotic-resistant strains $(\mathrm{n}=5)$

In case of antibiotic-susceptible $E$. coli strains, the values of IZD were similar to those determined by the antibiotics, the positive controls of the assay, while for the antibioticresistant strains significant differences were noticed when comparing to antibiotics - EEP combinations (Fig. 2) as follow: $\mathrm{P}<0.0001$ for AMC, CN, ENR and FFC and $\mathrm{P}<$ 0.001 for TE (P value determined by ANOVA analysis). The extracts solvent ( $70 \%$ ethanol) had not inhibitory activity on the studied strains indicating the antimicrobial efficacy of propolis against $E$. coli.

The minimum inhibitory concentrations (MICs) of the EEP ranged between 0.125 and $2 \%(\mathrm{v} / \mathrm{v})$ when tested against $E$. coli antibiotic-susceptible strains, while those obtained for antibiotic-resistant strains were between 2 and $4 \%(\mathrm{v} / \mathrm{v})$. As for the minimum bactericidal concentrations (MBCs), the values were similar or two times higher than MICs for both types of $E$. coli strains. The EEP effect against $E$. coli strains was considered bactericidal based on the interpretation previously established (Pavithra et al., 2010) for the ratio $\mathrm{MBC} / \mathrm{MIC}<4$ (Table 3).

A percentage change in the inhibition zone diameter $\geq$ $19 \%$ was noticed for $92 \%(23 / 25)$ of the EEP and antibiotics combinations; thus, according to the interpretation given by Nweze and Eze (2009), in vitro synergistic interactions (Table 4) were established between the EEP and five antibiotics frequently used in bovine pathology, including also $E$. coli induced mastitis. The synergism between EEP and antibiotics was observed for all the tested antimicrobials, except for florfenicol (Table 4) that in combination with EEP 1 and 3 displayed additive effect against the $E$. coli strains.

Based on the bacterial growth inhibition zone diameters and values determined as MICs and MBCs an important antimicrobial activity was demonstrated for all tested EEP. The antimicrobial potential of propolis extracts from different geographical locations was indicated by numerous studies (Bankova et al., 1995; Sforcin et al., 2000; Ugur et al., 2000; Banskota et al., 2001; Stepanović et al., 2003; Melliou and Chinou, 2004; Salomão et al., 2004; Popova et al., 2005; Orsi et al., 2006; Scazzocchio et al., 2006; Seidel et al., 2008; Raghukumar et al., 2010; Ramanauskienè et al., 2013). While several review and research articles described a broad spectrum of propolis and propolis compounds, with demonstrated activity against a wide range of organisms
(Mirzoeva et al., 1997; Ugur et al., 2000; Lotfy, 2006; Noori et al., 2012; Mărghitaş et al., 2013; Bankova et al., 2014), the information regarding the efficacy against $E$. coli is slightly contradictory. Generally, a stronger antibacterial effect is presented against the Gram-positive organisms (Banskota et al., 2001; Gonsales et al., 2006; Seidel et al., 2008; Raghukumar et al., 2010) and propolis extracts from different geographical areas appear to be particularly active against Staphylococcus aureus, both reference and clinical strains (Krol et al., 1993; Bankova et al., 1995; Fernandes Júnior et al., 2005; Gonsales et al., 2006; Scazzocchio et al., 2006; Alencar et al., 2007; de Andrade et al., 2009; Santana et al., 2012), including methicillin-resistant Staphylococcus aureus (MRSA) (Onlen et al., 2007; Raghukumar et al., 2010). Bankova et al. (1995) reported an important antibacterial efficacy of Brazilian propolis in relation to the phenolic compounds, confirmed also by Marcucci et al. (2001). The Brazilian red propolis was found active in vitro against reference strains Staphylococcus aureus ATCC 25923 and Staphylococcus mutans UA159, with the biologically active compounds belonging to flavonoids group (Alencar et al., 2007).

With regard to propolis antibacterial activity against $E$. coli, as opposed to certain data found in literature presenting weak or no activity against this bacterium (Bankova et al., 1999; Kosalec et al., 2005; Gonsales et al., 2006; Seidel et al., 2008), all tested EEP were found active in vitro against $E$. coli strains, both antibiotic-susceptible and antibioticresistant strains isolated from bovine mastitis. The Romanian propolis ethanolic extracts efficacy on $E$. coli was reported also by Mărghitaş et al. (2013), with inhibition zone diameters ranging between $7-12 \mathrm{~mm}$ and MIC of $0.625 \%(\mathrm{v} / \mathrm{v})$. These results are consistent also with those reported by Hegazi et al. (2000), which evaluated European propolis extracts obtained from France, Austria and Germany and observed antimicrobial activity against Staphylococcus aureus, Escherichia coli and Candida albicans. German propolis displayed the highest antimicrobial potential against Staphylococcus aureus and Escherichia coli and possessed significant high concentrations of flavonoids (Hegazi et al., 2000). Thus, the variations noticed in the antibacterial activity of propolis from distinct areas can be explained taking into consideration the chemical composition complexity of this natural product.

The antimicrobial potential of propolis was previously considered as a possible alternative for the bovine mastitis treatment, but such in vitro studies were focused on Staphylococcus aureus (Rindt et al., 2009a; Santana et al., 2012). A recent study pointed out the in vitro efficacy of Egyptian propolis on several Gram-positive bacteria isolated from bovine mastitis (Staphylococcus aureus, coagulasenegative staphylococci, Streptococcus agalactiae, Streptococcus dysgalactiae) and the lack of activity against Gram-negative bacteria (E. coli and Pasteurella spp.) (Hegazi et al., 2014).

To the best of authors' knowledge, this is the first study aimed to investigate the antibacterial activity of Romanian propolis and antibiotics combinations against antibioticsensitive and antibiotic-resistant $E$. coli strains isolated from bovine mastitis. Synergistic effects of tested EEP and five 
332

Table 4. Aspects of the interaction between EEP and E. coli antibiotic resistant strains $(\mathrm{n}=5)$

\begin{tabular}{llllll}
\hline & \multicolumn{5}{c}{ Ethanolic extracts of propolis (EEP) } \\
\hline Antibiotic & EEP 1 & EEP 2 & EEP 3 & EEP 4 & EEP 5 \\
\hline \multirow{2}{*}{ Amoxicillin/clavulanic acid, 20/10 $\mu \mathrm{g}$} & 32.73 & 27.27 & 41.82 & 47.27 & 34.55 \\
& synergism & synergism & synergism & synergism & synergism \\
Tetracycline, $30 \mu \mathrm{g}$ & 45.71 & 34.29 & 60.00 & 28.57 & 62.86 \\
& synergism & synergism & synergism & synergism & synergism \\
Gentamycin, $10 \mu \mathrm{g}$ & 48.00 & 56.00 & 60.00 & 62.00 & 64.00 \\
& synergism & synergism & synergism & synergism & synergism \\
Enrofloxacin, $5 \mu \mathrm{g}$ & 35.38 & 35.38 & 49.23 synergism & 64.62 & 50.77 \\
& synergism & synergism & synergism & synergism \\
\hline \multirow{2}{*}{ Florfenicol, $30 \mu \mathrm{g}$} & 17.00 & 22.00 & 18.00 & 32.00 & 23.00 \\
& additive & synergism & additive & synergism & synergism \\
\hline
\end{tabular}

Table 5. Pearson's correlation coefficients between flavones/flavonols, flavanones/dihydroflavonols, total phenolics and MIC, MBC towards E. coli antibiotic-resistant strains (MIC RS, MBC RS) and antibiotic-sensitive strains (MIC SS, MBC SS)

\begin{tabular}{|c|c|c|c|c|c|c|c|}
\hline Parameters & $\begin{array}{l}\text { Flavones/ } \\
\text { Flavonols }\end{array}$ & $\begin{array}{c}\text { Flavanones/ } \\
\text { Dihydro- } \\
\text { flavonols }\end{array}$ & $\begin{array}{c}\text { Total } \\
\text { phenolics }\end{array}$ & MICSS & MBCSS & MICRS & MBCRS \\
\hline Flavones/Flavonols & 1 & & & & & & \\
\hline Flavanones/Dihydro-flavonols & 0.427 & 1 & & & & & \\
\hline Total phenolics & 0.738 & $0.899^{* *}$ & 1 & & & & \\
\hline MICSS & -0.360 & $-0.922^{* *}$ & $-0.864^{*}$ & 1 & & & \\
\hline MBCSS & -0.492 & -0.677 & $-0.806^{*}$ & $0.881^{* *}$ & 1 & & \\
\hline MICRS & -0.418 & $-0.888^{* *}$ & $-0.827^{*}$ & $0.964^{* *}$ & $0.837^{*}$ & 1 & \\
\hline MBCRS & -0.620 & -0.476 & -0.511 & 0.456 & 0.385 & 0.667 & 1 \\
\hline $\mathrm{AMC}$ & 0.163 & 0.742 & 0.537 & $-0.771^{*}$ & -0.523 & $-0.888^{* *}$ & -0.750 \\
\hline $\mathrm{TE}$ & -0.419 & 0.336 & 0.162 & -0.333 & -0.187 & -0.091 & 0.653 \\
\hline $\mathrm{CN}$ & 0.505 & 0.691 & $0.825^{*}$ & $-0.882^{*}$ & $-0.998^{* *}$ & $-0.825^{*}$ & -0.354 \\
\hline ENF & 0.533 & $0.851^{*}$ & $0.823^{*}$ & $-0.898^{*}$ & $-0.781^{*}$ & $-0.979^{* *}$ & $-0.801^{*}$ \\
\hline FFC & $0.858^{*}$ & 0.482 & 0.685 & -0.515 & -0.603 & -0.665 & $-0.903^{* *}$ \\
\hline
\end{tabular}

${ }^{*} \mathrm{P}<0.05$ and $^{* *} \mathrm{P}<0.01$

antibiotics (amoxicillin/clavulanic acid, tetracycline, gentamycin, enrofloxacin and florfenicol) against E. coli strains of bovine origin were observed.

The synergistic activity between propolis and antibiotics was reported by other authors (Stepanović et al., 2003; Orsi et al., 2006; Scazzocchio et al., 2006; Orsi et al., 2012), but most of these studies included Staphylococcus spp., mainly Staphylococcus aureus strains (Krol et al., 1993; Stepanović et al., 2003; Fernandes Júnior et al., 2005; Onlen et al., 2007). From the group of Gram-negative bacteria, Salmonella Typhi manifested in vitro an enhanced susceptibility towards combinations between both Brazilian and Bulgarian propolis and antibiotics such as amoxicillin, ampicillin and cephalexin (Orsi et al., 2006; Orsi et al., 2012), with similar MICs (9.90 and 10.0\%, respectively), but with different types of action: bacteriostatic activity in case of Brazilian propolis, while the Bulgarian one acted bactericidal (Orsi et al., 2006).

The ability of propolis extracts to potentiate the antimicrobial activity of other substances was reported also in case of essential oils (Probst et al., 2011), honey (Noori et al.,2012), lysozyme (Ramanauskienè et al., 2009).

According to scientific literature, certain mechanisms associated with such synergistic effects may encompass flavonoids from propolis conferring several antibacterial properties: a decreased resistance of the bacterial wall that becomes more susceptible to antibiotics (Pascoal et al., 2014), direct inhibitory effect on ribosomes (Sforcin and Bankova, 2011; Orsi et al., 2012; Pascoal et al., 2014), inhibition of several bacterial enzymes (Daglia, 2012), alteration of bacterial protein expression (Daglia, 2012), modulation of $\beta$-lactam resistance (Cushnie and Lamb, 2011).

Given the great variability of the chemical composition of propolis and the propolis compounds role in the expression of antimicrobial potential, Popova et al. (2005) stated that a complete characterization of this property should involve qualitative and quantitative chemical analysis. Additionally, scientific data demonstrated that quantification of propolis active principles as groups of compounds correlated better with biological activity, especially the antimicrobial action, than the quantification of individual constituents (Popova et al., 2010). Therefore, following the chemical characterisation of EEP, with the flavonoids and total phenolics quantitative determination and the chromatographic identification of phenolic compounds, and the antibacterial potential evaluation, Pearson correlation coefficients were calculated between these parameters (Table 5).

Flavanones/dihydroflavonols were significantly negatively correlated with MICs for both antibioticsensitive $E$. coli strains $\left(\mathrm{r}^{2}=-0.922\right)$ and antibiotic-resistant E. coli strains $\left(\mathrm{r}^{2}=-0.888\right)$. The results also indicated a very strong negative correlation between total phenolics with MICs for antibiotic-sensitive $E$. coli strains $\left(\mathrm{r}^{2}=-0.864\right)$ and antibiotic-resistant $E$. coli strains $\left(\mathrm{r}^{2}=-0.827\right)$ and a similar pattern in case of total phenolics with MBCs $\left(\mathrm{r}^{2}=-\right.$ 0.806 for antibiotic-sensitive $E$. coli strains and $\mathrm{r}^{2}=-$ 0.511 for antibiotic-resistant E. coli strains). Previous study (Bankova, 2005) had already demonstrated strong negative correlation between the concentration of total phenolics in propolis and MIC the greater the concentration, the lower the MIC $(P=0.003)$. This data supports the concept that 
measuring the concentrations of groups of active compounds instead of that of individual components is the right approach in the case of propolis (Bankova, 2005; Popova et al., 2007).

Our results showed that combinations between propolis and antibiotics have synergistic effect against $E$. coli strains and the enhanced antimicrobial efficacy was related to the EEP chemical composition (Table 5), with flavone/flavonols strongly positive correlated with florfenicol $\left(r^{2}=0.858\right)$ and flavanone/dihydroflavonols strongly positive correlated with enrofloxacin $\left(r^{2}=0.851\right)$. In addition, total phenolics proved strong positive correlation with all tested antibiotics: enrofloxacin $\left(r^{2}=0.823\right)$, gentamycin $\left(r^{2}=0.825\right)$, flofenicol $\left(r^{2}\right.$ $=0.685)$, amoxicillin/clavulanic acid $\left(r^{2}=0.537\right)$, except for tetracycline $\left(r^{2}=0.162\right)$.

Phenolic compounds such as flavonoids represent a key element of propolis samples characterization in connection with the biological activity of this natural product (Bankova et al., 1995; De Castro, 2001; Marcucci et al., 2001; Kosalec et al., 2005; Gonsales et al., 2006; Alencar et al., 2007). Thus, the identification and quantification of phenolic compounds in Romanian propolis ethanolic extracts indicate not only the authenticity and the quality of tested EEP, but also underline the complex antimicrobial potential manifested against $E$. coli and moreover in the form of synergism with antibiotics.

\section{Conclusions}

The study indicated for Romanian propolis ethanolic extracts the typical poplar composition profile with flavonoids and phenolic acids as main biological active compounds, with chromatographic analysis data confirmed also spectrophotometrically. Furthermore, a strong antimicrobial efficacy positively correlated to the chemical composition was exhibited against $E$. coli strains isolated from bovine mastitis, along with interesting synergistic interaction with antibiotics that can be further investigated to obtain propolis-based formulation with antibacterial properties. Subsequent in vitro and in vivo studies evaluating the safety and efficacy are intended to consider propolis in veterinary therapeutic protocols.

\section{Acknowledgements}

This work was done under the frame of European Social Fund, Human Resources Development Operational Programme 2007-2013, Project number POSDRU/159/1.5/S/ 136893.

\section{References}

Alencar SM, Oldoni TLC, Castro ML, Cabral ISR, Costa-Neto CM, Cury JA, ... Ikegaki M (2007). Chemical composition and biological activity of a new type of Brazilian propolis: red propolis. Journal of Ethnopharmacology 113(2):278-283.

Bankova V (2005). Chemical diversity of propolis and the problem of standardization. Journal of Ethnopharmacology 100(1):114117.

Bankova V, Christov R, Kujumgiev A, Marcucci MC, Popov S (1995). Chemical composition and antibacterial activity of Brazilian propolis. Zeitschrift für Naturforschung $50 \mathrm{C}(3-4): 167-172$.

Bankova V, Christov R, Popov S, Marcucci MC, Tsvetkova I, Kujumgiev A (1999). Antibacterial activity of essential oils from Brazilian propolis. Fitoterapia 70(2):190-193.

Bankova V, Popova M, Trusheva B (2014). Propolis volatile compounds: chemical diversity and biological activity: a review. Chemistry Central Journal 8(1):28.
Bankova V, Popova M, Bogdanov S, Sabatini AG (2002).Chemical composition of European propolis: expected and unexpected results. Zeitschrift für Naturforschung C 57(5-6):530-533.

Banskota AH, TezukaY, Kadota S (2001). Recent progress in pharmacological research of propolis. Phytotherapy Research 15(7):561571.

Barbarić M, Mišković K, Bojić M, Lončar MB, Smolčić-Bubalo A, Debeljak Z, Medić-Šarić M (2011). Chemical composition of the ethanolic propolis extracts and its effect on HeLa cells. Journal of Ethnopharmacology 135(3):772-778.

Bradley AJ (2002). Bovine mastitis: an evolving disease. The Veterinary Journal 164(2):116-128.

Clinical and Laboratory Standards Institute (CLSI): M100-S23 (2013). Performance Standards for Antimicrobial Susceptibility Testing; TwentyThird Informational Supplement. 33.

Cushnie TPT, Lamb AJ (2011). Recent advances in understanding the antibacterial properties of flavonoids. International Journal of Antimicrobial Agents 38(2):99-107.

Dagiia M (2012). Polyphenols as antimicrobial agents. Current Opinion in Biotechnology 23:174181.

de Andrade UVC, Hartmann W, Funayama S, de Alencar SM, Masson ML (2009). Propolis obtained by means of alkaline hydrolysis and action on Staphylococcus aureus. Ars Veterinaria 25(3):151-154.

De Castro SL (2001). Propolis: Biological and pharmacological activies. Therapeutic uses of this bee-product. Annual Review of Biomedical Sciences 3:49-83.

Dobrowolski JW, Vohora SB, Sharma K, Shah SA, Naqvi SAH, Dandiya PC (1991). Antibacterial, antifungal, antiamoebic, antiinflamatory and antipyretic studies on propolis bee products. Journal of Ethnopharmacology 35:77-82.

Down PM, Green MJ, Hudson CD (2013). Rate of transmission: A major determinant of the cost of clinical mastitis. Journal of Dairy Science 96(10):6301-6314.

Fernandes Júnior A, Balestrin EC, Betoni JEC, Orsi RDO, da Cunha MLRS, Montelli AC (2005). Propolis: anti-Staphylococcus aureus activity and synergism with antimicrobial drugs. Memórias do Instituto Oswaldo Cruz 100(5):563-566.

Gekker G, Hu S, Spivak M, Lokensgard JR, Peterson PK (2005). Anti-HIV-1 activity of propolis in CD4+ lymphocyte and microglial cell cultures. Journal of Ethnopharmacology 102(2):158-163.

Gonsales GZ, Orsi RO, Fernandes Jr A, Rodrigues P, Funari SRC (2006). Antibacterial activity of propolis collected in different regions of Brazil. Journal of Venomous Animals and Toxins Including Tropical Diseases 12(2):276-284.

Halasa T, Huijps K, Østerås O, Hogeveen H (2007). Economic effects of bovine mastitis and mastitis management: A review. Veterinary Quarterly 29(1):18-31.

Hegazi AG, Abd El Hady FK, Abd Allah FA (2000). Chemical composition and antimicrobial activity of European propolis. Zeitschrift fürNaturforschung C 55(1-2):70-75.

Hegazi AG, Abdou AM, Allah FA (2014). Antimicrobial Activity of Propolis on the Bacterial Causes of Mastitis. Life Science Journal 11(5):572-576.

Huang S, Zhang CP, Wang K, Li GQ, Hu FL (2014). Recent advances in the chemical composition of propolis. Molecules 19(12):19610-19632.

Kalogeropoulos N, Konteles SJ, Troullidou E, Mourtzinos I, Karathanos VT (2009). Chemical composition, antioxidant activity and antimicrobial properties of propolis extracts from Greece and Cyprus. Food Chemistry 116(2):452-461.

Khalil ML (2006). Biological activity of bee propolis in health and disease. Asian Pacific Journal of Cancer Prevention 7(1):22-31.

Kosalec I, Pepeljnjak S, Bakmaz M, Vladimir-Knežević S (2005). Flavonoid analysis and antimicrobial activity of commercially available propolis products. Acta Pharmaceutica 55(4): $423-430$.

Krol W, Scheller S, Shani J, Pietsz G, Czuba Z (1993). Synergistic effect of ethanolic extract of propolis and antibiotics on the growth of Staphylococcus aureus. Arzneimittel-Forschung 43(5):607-609. 
334

Laslo L (2007). Evaluarea unor markeri de calitate şi autenticitate a propolisului [Evaluation of propolis quality and authenticity markers] $\mathrm{PhDThesis}$ (in Romanian), USAMV, Cluj-Napoca.

Lotfy M (2006). Biological activity of bee propolis in health and disease. Asian Pacific Journal of Cancer Prevention 7(1):22-31.

Marcucci MC, Ferreres F, Garcia-Viguera C, Bankova VS, De Castro SL, Dantas AP, ... Paulino N (2001). Phenolic compounds from Brazilian propolis with pharmacological activities. Journal of Ethnopharmacology 74(2):105-112

Mărghitaş LA, Dezmirean DS, Bobiş O (2013). Important developments in Romanian propolis research. Evidence-Based Complementary and Alternative Medicine, http://dx.doi. org/10.1155 /2013/159392.

Melliou E, Chinou I (2004). Chemical analysis and antimicrobial activity of Greek propolis. Planta Medica 70(6):515-519.

Noori AL, Al-Ghamdi A, Ansari MJ, Al-Attal Y, Salom K (2012). Synergistic effects of honey and propolis toward drug multi-resistant Staphylococcus aureus, Escherichia coli and Candida albicans isolates in single and polymicrobial cultures. International Journal of Medical Sciences 9(9):793.

Nweze EI, Eze EE (2009). Justification for the use of Ocimum gratissimum $\mathrm{L}$ in herbal medicine and its interaction with disc antibiotics. BMC Complementary and Alternative Medicine 9:37.

Onlen Y, Duran N, Atik E, Savas L, Altug E, Yakan S, Aslantas O (2007). Antibacterial activity of propolis against MRSA and synergism with topical mupirocin. The Journal of Alternative and Complementary Medicine 13(7):713-718.

Orsi RDO, Sforcin JM, Funari SRC, Fernandes Junior A, Bankova V (2006). Synergistic effect of propolis and antibiotics on the Salmonella typhi. Brazilian Journal of Microbiology 37(2):108-112.

Orsi RO, Fernandes A, Bankova V, Sforcin JM (2012). The effects of Brazilian and Bulgarian propolis in vitro against Salmonella Typhi and their synergism with antibiotics acting on the ribosome. Natural Product Research 26(5):430-437.

Oršolić N (2010). A review of propolis antitumor action in vivo and in vitro. Journal of ApiProduct and ApiMedical Science 2(1):1-20.

Pascoal A, Feás X, Dias T, Dias LG, Estevinho LM (2014). The Role of Honey and Propolis in the Treatment of Infected Wounds. In: Kon K Rai M (Ed). Microbiology for Surgical Infections: Diagnosis, Prognosis and Treatment. Elsevier, pp 221-234.

Pavithra PS, Janani VS, Charumathi KH, Indumathy R, Potala S, Verma RS (2010). Antibacterial activity of plants used in Indian herbal medicine. International Journal of Green Pharmacy 4:22-28.

Popova M, Bankova V, Butovska D, PetkovV, Nikolova-Damyanova B, Sabatini AG, ... Bogdanov S (2004). Validated methods for the quantification of biologically active constituents of poplar-type propolis. Phytochemical Analysis 15(4):235-240.

Popova M, Silici S, Kaftanoglu O, Bankova V (2005). Antibacterial activity of Turkish propolis and its qualitative and quantitative chemical composition. Phytomedicine 12(3):221-228.

Popova MP, Bankova VS, Bogdanov S, Tsvetkova I, Naydenski C, Marcazzan GL, Sabatini AG (2007). Chemical characteristics of poplar type propolis of different geographic origin. Apidologie 38(3):306-311.

Popova M, Chen CN, Chen PY, Huang CY, Bankova V (2010). A validated spectrophotometric method for quantification of prenylated flavanones in pacific propolis from Taiwan. Phytochemical Analysis 21(2):186-191.

Probst IS, Sforcin JM, Rall VLM, Fernandes AAH, Fernandes Júnior A (2011). Antimicrobial activity of propolis and essential oils and synergism between these natural products. Journal of Venomous Animals and Toxins including Tropical Diseases 17(2):159-167.

Quiroga EN, Sampietro DA, Soberón JR, Sgariglia MA, Vattuone MA (2006). Propolis from the northwest of Argentina as a source of antifungal principles. Journal of Applied Microbiology 101(1):103-110.

Raghukumar R, Vali L, Watson D, Fearnley J, Seidel V (2010). Antimethicillin-resistant Staphylococcus aureus (MRSA) activity of 'pacific propolis' and isolated prenylllavanones. Phytotherapy Research 24(8):1181-1187.
Ramanauskienė K, Inkènienè AM, Petrikaite V, Briedis V (2013). Total phenolic content and antimicrobial activity of different lithuanian propolis solutions. Evidence-Based Complementary and Alternative Medicine 842985 doi:10.1155/2013/842985.

Ramanauskienè K, Inkeniene AM, Savickas A, Masteikova R, Brusokas V (2009). Analysis of the antimicrobial activity of propolis and lysozyme in semisolid emulsion systems. Acta Poloniae Pharmaceutica Drud Research 66(6):681-688.

Rindt IK, Sandru CD, Brudasca F, Niculae M, Kobolkuti L, Cadar D, ... Spinu M (2009a). Antibacterial activity of different propolis concentrations against Staphylococcus aureus stains isolated from bovine mastitis. Lucrări Sțiințifice-Medicină Veterinară, Universitatea de Științe Agricole si Medicină Veterinară "Ion Ionescu de la Brad" Iași, 52(11 (2):1096-1098.

Rindt IK, Spânu M, Niculae M, Szakacs BS, Bianu G, Laslo L (2009b). The immunostimulatory activity of propolis from different origin. Veterinary Medicine Scientific Papers 42(1):350-353.

Ruegg PL (2009). Management of mastitis on organic and conventional dairy farms. Journal of Animal Science 87(13_suppl):43-55.

Sahinler N, Kaftanoglu O (2005). Natural product propolis: chemical composition. Natural Product Research 19(2):183-188.

Salomão K, Dantas AP, Borba CM, Campos LC, Machado DG, Aquino Neto FR, de Castro SL (2004). Chemical composition and microbicidal activity of extracts from Brazilian and Bulgarian propolis. Letters in Applied Microbiology 38:87-92.

Santana HF, Barbosa AAT, Ferreira SO, Mantovani HC (2012). Bactericidal activity of ethanolic extracts of propolis against Staphylococcus aureus isolated from mastitic cows. World Journal of Microbiology and Biotechnology 28(2):485-491.

Scazzocchio F, D’auria FD, Alessandrini D, Pantanella F (2006). Multifactorial aspects of antimicrobial activity of propolis. Microbiological Research 161(4):327-333.

Schnitzler P, Neuner A, Nolkemper S, Zundel C, Nowack H, ... Reichling J (2010). Antiviral activity and mode of action of propolis extracts and selected compounds. Phytotherapy Research 24(S1):S20-S28.

Seidel V, Peyfoon E, Watson DG, Fearnley J (2008). Comparative study of the antibacterial activity of propolis from different geographical and climatic zones. Phytotherapy Research 22(9):1256-1263.

Sforcin JM, Bankova V (2011). Propolis: is there potential for the development of new drugs? Journal of Ethnopharmacology 133:253-260.

Sforcin JM, Fernandes A, Lopes CAM, Bankova V, Funari SRC (2000). Seasonal effect on Brazilian propolis antibacterial activity. Journal ofEthnopharmacology 73(1):243-249.

Silva JC, Rodrigues S, Feás X, Estevinho LM (2012). Antimicrobial activity, phenolic profile and role in the inflammation of propolis. Food and Chemical Toxicology 50(5):1790-1795.

Stan L, Niculae M, Mărghitaş LA, Spînu M, Dezmirean D (2012). Antibacterial effect of Romanian propolis on Pseudomonas aeruginosa and Staphylococcus intermidius. Planta Medica 78(11):PD98.

Stan L, Mărghitaş LA, Dezmirean D (2011). Quality criteria for propolis standardization. Scientific Papers Animal Science and Biotechnologies 44(2):137-140.

Stepanović S, Antić N, Dakić I, Švabić-Vlahović M (2003). In vitro antimicrobial activity of propolis and synergism between propolis and antimicrobial drugs. Microbiological Research 158(4):353-357.

Ugur A, Barlas M, Ceyhan N, Turkmen V (2000). Antimicrobial Effects of Propolis Extracts on Escherichia coli and Staphylococcus aureus Strains Resistant to Various Antibiotics and Some Microorganisms. Journal of Medicinal Food 3(4):173-180.

Uzel A, Sorkun K, Onçă̆ O, Cogŭlu D, Gençay O, Salih B. (2005). Chemical compositions and antimicrobial activities of four different Anatolian propolis samples. Microbiological Research 160:189-195.

Viguier C, Arora S, Gilmartin N, Welbeck K, O'Kennedy R (2009). Mastitis detection: current trends and future perspectives. Trends in Biotechnology 27(8):486-493. 